\begin{tabular}{|c|c|}
\hline & $\begin{array}{l}\text { International Journal of Trend in Scientific } \\
\text { Research and Development (IJTSRD) }\end{array}$ \\
\hline 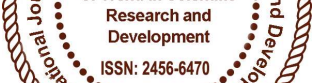 & International Open Access Journal \\
\hline 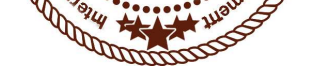 & ISSN No: 2456 - 6470 | www.ijtsrd.com | Volume - 2 | Issue - 2 \\
\hline
\end{tabular}

\title{
Weaver's Attitude on Implementation of Integrated Handloom Cluster Development Scheme (IHCDS): An Empirical Study
}

\author{
Prof. K. Rama Mohana Rao \\ Professor, Department of Commerce \\ and Management Studies, Andhra \\ University, Visakhapatnam, India
}

\author{
Kakumanu Kiran Kumar \\ Research Scholar, Department of Commerce \\ and Management Studies, Andhra \\ University, Visakhapatnam, India
}

\section{ABSTRACT}

The handloom industry plays a vital role in the Indian economy. It is one of the largest economic activities providing direct employment to the persons engaged in weaving and allied activities. Handloom sector contributes nearly 19 percent of the total cloth produced in the country and also adds substantially to export earnings. As a result of effective Government intervention through financial assistance and implementation of various developmental and welfare schemes, this sector has been able to withstand competition from the power loom and mill sectors. However, handloom industry faces a number of problems and challenges, and these are adversely affecting its continued growth and sustainability. This paper analyses the Weaver's opinion on Implementation of Integrated Handloom Cluster Development Scheme (IHCDS) and puts forward some measures for improving the welfare of the handloom workers.

Keywords: weavers, opinion, handloom, industry

\section{Introduction}

The importance of small enterprises in rural areas in emerging economies is generally acknowledged by many researchers and practitioners (Van Dijk, 2000). Many village enterprises in India are traditional in nature where the technology is not sophisticated and the training is informal passed on from older family members to the younger members. Cottage and village industries are those in which manufacturing occurs on a very small scale by a particular family or group of persons. Thus, those industries in which artisans have a setup in their own houses, work with wood, cane, brass, stone etc. are called cottage industries. Handloom weaving is the most important cottage industry and one of the earliest to come into existence in India (Jayavel, 2013).

A handloom forms a part of the heritage of India and exemplifies the richness and diversity of our country and the artistry of the weavers (Fayaz Ahmad and Hussain, 2013). The popular belief is that the handloom industry has survived only because of government support (Tasneem Shazli and Abdul Munir, 2014). However, an alternative viewpoint suggests that the industry endured because of its ability to adapt to the challenging needs of the textile markets of India by providing quality goods with skillful designs (Mukund and Sundari, 2001; Bharatan, 1988). A look at the handloom industry over the past years reveals that the changes in production technology are few but the changes in the market are substantial. While handlooms has been losing the low end market to the power looms, it has been gaining new ground in the high and mid-range markets with its creation of new niches.

Handlooms have always been a sector of high importance in the policy framework of the Government of India. In 1975, Office of Development Commissioner for Handlooms, a separate Directorate 
with sole responsibility for dealing with Handlooms, was established. The office of the Development Commissioner for Handlooms has the mandate to develop a strong, competitive and vibrant handloom sector to provide sustainable employment to the weavers. It implements all the schemes pertaining to Handloom Sector and also enforces the Handloom Reservation Act, 1985.

The very presence of a firm in the mainstream production centre and the economies of operative knowledge gathered thereby through interaction with fellow enterprises, machinery and raw material suppliers, stockist and traders; provide critical information which can guide an enterprise's entire production, technology and marketing technique in a typically symbiotic relationship (Schmitz: 1999). Advantage of location is all-pervasive. In fact, what has de-facto occurred is that the contours of 'Competitiveness' have undergone a paradigm shift. Local availability of raw material, cheap labour, lack of capital or 'technology' no more rules the roost of 'competitiveness'. The answer really lies in the business environment exogenous to the firms or even outside its industry, residing instead in the location of business units (Porter: 1998).

A cluster is not merely a physical existence of a group of firms but it is the chemistry of their relationship that characterizes the difference. A cluster has several dimensions (Enright: 1998). 'Working Clusters' clusters are those in which a critical mass of local knowledge, expertise, personnel, and resources create agglomeration economies that are used by firms to their advantage in competing with those outside the cluster. Working clusters tend to have dense patterns of interactions among local firms that differ quantitatively and qualitatively from the interactions that the firms have with those not located in the cluster. Working clusters often have complex patterns of competition and co-operation and often are able to attract mobile resources and key personnel from other locations. Even if participants do not call themselves a 'cluster' there tends to be knowledge of the interdependence of local competitors, suppliers, customers, and institutions.

\section{Integrated Handloom Cluster Development Scheme (IHCDS) in Andhra Pradesh}

Several schemes are being implemented for SocioEconomic Development of Handloom Weavers in
Andhra Pradesh both through 100 per cent State and Central Government Schemes and matching schemes of the Central Government with State matching share as per the budget provisions. The Government of Andhra Pradesh also implemented the Centre initiated Integrated Handloom Cluster Development Scheme (IHDS) in 2007-08 with the following specific objectives.

- Focus on formation of Handloom Weavers Group as a visible entity.

- Develop the Handloom Weavers Groups to become self-sustainable.

- Inclusive approach to cover weavers both Cooperative and Outside Co-operative Fold.

- Skill Up-gradation of Handloom Weavers/ Workers to produce diversified products with improved quality to meet the market requirements.

In addition to the Central Government Schemes, the State Government also introduced some schemes for the development of socio economic conditions of the weavers and also the industry as a whole. The following are some of the schemes of the State Government such as: Interest Subsidy, Old Age Pensions to / Weavers, State Government Loan Weavers Scheme, Indiramma Housing Programme, Payment of Ex-Gratia to the Families of Suicidal Weavers, Establishment of Samishti Handloom Sales Emporia, Netha Bazaars, Scheme for Training and Infrastructural support to Handloom Sector, and Subsidy on Purchase Hank Yarn, Dyes \& Chemicals from NHDC and APCO.

\section{Review of Literature}

Rejula Devi (1983) suggested that the government should take care of the handloom industry by allocating huge resources for the development of the industry. According to the researcher, the handloom industry in recent years has fallen into deeper crisis, because of lack of adequate financial support. Socioeconomic condition of the majority of weavers is not in a better position and the weavers are trying to give up their profession and go to alternative works. Another effort to analyze the nature of cotton handloom industry in India has been made by Rama Mohan Rao K. (1990) in his book "Development of Handloom Industry" has touched the socio-economic profile of the weavers in handloom industry in Andhra Pradesh. He has presented an overall view of the performance of primary weavers' co-operative societies. Pani B.S. (1990) in his paper on "Handloom 
Development Policy-A critical Appraisal" concludes that, the handloom sector is now facing a deeper crisis and it may have to face the danger of its liquidation in the coming decade, if present trends continue. He suggested measures like, modernizing the handloom sector on a war footing plane, altering the production structure to suit consumer preferences, strengthening the private sector in the handloom industry, scrapping the controlled cloth scheme, regulating the supply and prices of yarn, chemicals and dyes and enforcing restrictions on further expansion of capacity in mills and power looms.

Joglekar and Prabhakara Sharma (2002) have emphasized that the area under cotton cultivation in India is the largest in the world. India has the second largest spinning capacity after China in hand weaving sector and a long tradition of producing some of the finest and costliest fabrics in the world. India is the biggest yarn exporter with the share of 28 per cent of the world market and is known for the quality of its fine count cotton yarns. Through the contribution of the state handloom to the Indian culture as well as to the national exchequer presents a satisfactory picture. An insight into the socio-economic and working conditions of the weavers is tough one. At present, most of the weavers are leading miserable life for which the main reason is due to improper technology and also the fruits of the industry are actually grabbed by the middlemen. Asha Krishna Kumar (2003) points out the need for the expansion of domestic and international market for Indian Handloom products. The researcher argued that in the era of globalization when the market is flooded with textiles from China and other countries, the regional specialization of handlooms, of which the list is endless, can be used to provide a well-defined product identity. Lakshmi Narasaiah M. (2004) stated that the problem of illiteracy in weaver's community is unchecked status. He opined the need to arrange special schools for weavers community with technical training related to the weaving. Subbaraj and Joseph stated that a mix of strategies adopted by co-operative of weavers constituted them in the environment but not the market environment.

Sinha (2005) has analyzed the status of women and economic development in India. She has also analyzed the regional pattern in female participation in handloom weaving. Annapurana (2006) in her paper on "Transitioning Markets - Transcending Consumption" opined that, despite many anticipations of the decline of handloom sector, the resilience of the handloom market in India demonstrates an inherent quality of the product as well as the many intangible associations it carries for its customers. The firms associated with the marketing of handloom products must use different strategies to face various challenges. Ashis mitra et al. (2009) stated that in the process of developing traditional Indian handloom cluster, the development commissioner for handloom ministry of textiles implemented 'Integrated Handloom Cluster Development Scheme' (IHCDS) since the year 2005-06, to build the clusters capacity to overcome the market and to strengthen them to compete at global level. The study explains how to overcome the hurdles of textile business as well as marketing plans in Shanthipur handloom cluster. Out of the three series of this study, part one explains evolution and historical background of the cluster. A diagnostic report on cluster development programme of Shanthipur handloom cluster of Nadia, West Bengal state which formulate a sustainable business plan and marketing plan to help this cluster in textile business. It also explains the historical background of cluster and its geographical location, structure, and infrastructure analysis to make sustainable business and market plan.

Margaret C. Perivoliotis (2009) studied the diachronic aesthetic powers of hand looming and interlacing techniques. Author successfully evaluated the cultural significance of the ancient handicraft techniques. This case study explains looming and weaving methodology in modern hand craft production. It also tried to show the possibility for modern jewels and results from specific methods theoretically and practically. New quality jewelry designs with the adaption of traditional handicraft methodologies are also attempted. The case study promotes teaching projects in jewelry design. The teaching assignments / textile design education development leads innovation in the handicraft field. Merima Ali (2010) studied the handloom industry in four regions of Ethiopia. The findings of this study revealed the importance of cluster- based industrial activities as a reciprocal method of scattering indoctrination when local conditions do not allow easy access to credit. Specialization and division of labour minimize the barriers of minimizing the initial capital required to start a business of handloom sector in the four regions of Ethiopia. This effect is found to be notably larger for micro enterprises investing in districts with higher grades of capital market inefficiency, pointing out the 
importance of clustering as an organizational response to a confined credit environment. Kuldeep Singh and Monica Bansal (2012) mentioned the handloom sector plays an important role in a country's economy providing direct employment of 65 lakh persons in weaving. Governments integrating through financial access and implementation of welfare schemes made this sector to compete with power loom sector and mill sectors. The flexibility and veracity of handloom encouraged the innovations through experimentation. The unique innovative designing is the strength of handloom where power loom sector cannot replicate that. Hence, handloom is the integral part of own country's heritage synonymous for its riches, diversities and the weavers.

Srinivasa Rao and Kasisomayajula (2012) stated handloom industry in India is an ancient cottage industry with a decentralized setup. Handloom industry is highly concentrated on manmade art and tradition. The handloom sector plays a very important role in the country's economy. Tracing the importance of the textile sector in the Indian economy also brings us face to face with the different components such as the mill segment, the handloom segment and the power loom segment that make up this whole. In handloom sector weavers are classified into independent weavers, weavers working under master weavers, weavers working for cooperative societies, weavers for non-government organizations and shed (wage) weavers. The Handloom Industry has not received the attention by the economists and researchers what they deserves. Krishna Reddy and Noorbasha Abdul (2013) have examined the current challenges being faced by the handloom industry in the state of Andhra Pradesh. They opined that the reforms-led crisis in the handloom industry has thrown out thousands of weavers' from regular employment. The study identified that some of the micro-finance schemes currently being in implementation in the state of the debt ridden, unskilled and reemployed handloom weavers in the state period and seems to have slowed down the rate of poverty reduction.

Rayapati Raveendranadh (2013) mentioned that marketing and distribution system is conventional type for handloom in west Bengal, Tamilnadu, Uttarpradesh, Andhra Pradesh, Assam, and Manipur. More than 75 percent of handloom weaving comes from these states, for domestic market. Marketing is the biggest hurdle for handloom sector, where the middlemen play an important role in selling cloth to consumer. The poor weaver's family gets harmed by delay in marketing of cloth. The power loom takes a supreme position in textiles in India, and encourages the same for traditional sector of handlooms. Rubyjain and Rachana Goswami (2013) have made a mention in their study that handloom industry is perhaps the most important among the hundreds of small scale and cottage arts and crafts that have survived in India. The study focused on the awareness level and social demographic profile of the handloom weavers of Jaipur district. The study found that there is an overall low level of awareness among the weavers on various aspects of a cooperative society and government programmes. The researcher suggests various steps to strengthen the productivity of the weavers. Rachana Goswami and Ruby Jain (2014) stated that the handloom sector of India is an important part of the country's economy as well as socio- cultural traditions and has been sustaining by transferring skills from one generation to the next. Though government of India is consistently pursuing to bring about improvement in the productivity and marketing of handloom sector, the weavers are facing severe livelihood crisis. According to the researchers, the handloom organizations are not following suitable strategies for procurement of raw material, product planning and promotion.

The study of Vijayabhaskar (2014) reveals the existence of handloom dates from times immemorial in "India. Though handloom literally refers to a traditional weaving method, symbolically it stands from much more. It represents a philosophy- a way of life. The philosophy is the simple faith of Indian folk artisan- the handloom weaver- the man behind the loom. Handloom stands for the revitalization of traditional creative energies and the certainty that they can be infused into our modern civilization. Though the method employed in making handloom products are simple, the results are extraordinary. The human effort results in creation which are both aesthetically delightful and extremely durable. The studies referred in the earlier paragraphs confined to either certain regions or some specific issues of handloom industry. None of the studies focused on handloom clusters and measured the impact of the clusters on the socioeconomic conditions of the weavers. The present study has been taken up to fill the gap and to contribute for the development of the handloom industry. 


\section{Objectives of the Study}

The main objective of the study is to analyze the opinion of the weavers on implementation of Integrated Handloom Cluster Development Scheme (IHCDS) in Andhra Pradesh, India.

\section{Research Methodology and Hypotheses}

The required data are collected through primary and secondary sources. The secondary data was collected from the Department of Handlooms and Textiles, Government of Andhra Pradesh, APCO, and other related government offices. Data and information was also collected from research reports, journals, publications and district offices. Secondary data are also collected from the administrative office of the selected clusters. The primary data was collected from weavers working under cluster scheme. The Andhra Pradesh state is selected for the study. Since the weavers are present in all most all the district of Andhra Pradesh in large number, the census study is beyond the capacity of the researcher. Therefore, three districts namely Ananthapur, East Godavari, and Srikakulam are selected based on existence of large number of clusters compared to other districts of
Andhra Pradesh. The member weavers of all the 14 clusters form the sample frame. Survey method is used to collect information from weavers. The research instrument was structured questionnaire. Since the size of the population is large, quota sampling method is used to decide sample size. The size of the sample for each district was 150 weavers working under cluster scheme. Thus, the sample size of the three selected districts was 450. Simple random sampling technique is used to select sample units.

The following hypotheses have been formulated for testing:

$\mathrm{H}_{0}$ : The member weavers have highly positive opinion on implementation of IHCDS.

$\mathrm{H}_{\mathrm{A}}$ : The member weavers do not have highly positive opinion on implementation of IHCDS.

\section{Demographic Profile Of The Respondents}

The study analyzes the demographic profile of the respondents with reference to age, gender, education background, monthly income, and place of residence as shown in table 1 .

Table 1: Demographic Profile of Respondents $(n=450)$

\begin{tabular}{|c|c|c|c|c|}
\hline \multirow[t]{2}{*}{ Factor } & \multicolumn{3}{|l|}{ Districts } & \multirow[t]{2}{*}{ Total } \\
\hline & Srikakulam & Guntur & East Godavari & \\
\hline Age & \multicolumn{4}{|c|}{ 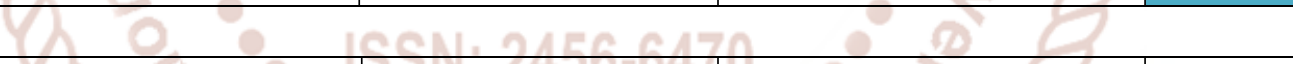 } \\
\hline $30 \&$ below & $\begin{array}{l}8 \\
(1.77)\end{array}$ & $\begin{array}{l}9 \\
(1.99)\end{array}$ & $\begin{array}{l}11 \\
(2.44)\end{array}$ & $\begin{array}{l}28 \\
(6.22)\end{array}$ \\
\hline $31-40$ & $\begin{array}{l}48 \\
(10.66)\end{array}$ & $\begin{array}{l}36 \\
(8.00)\end{array}$ & $\begin{array}{l}33 \\
(7.33)\end{array}$ & $\begin{array}{l}117 \\
(26.00)\end{array}$ \\
\hline $41-50$ & $\begin{array}{l}48 \\
(10.66)\end{array}$ & $\begin{array}{l}38 \\
(8.44)\end{array}$ & $\begin{array}{l}42 \\
(9.33)\end{array}$ & $\begin{array}{l}128 \\
(28.44)\end{array}$ \\
\hline Above 50 & $\begin{array}{l}46 \\
(10.22)\end{array}$ & $\begin{array}{l}67 \\
(14.88)\end{array}$ & $\begin{array}{l}64 \\
(14.22)\end{array}$ & $\begin{array}{l}177 \\
(39.33)\end{array}$ \\
\hline \multicolumn{5}{|l|}{ Gender } \\
\hline Male & $\begin{array}{l}101 \\
(22.44)\end{array}$ & \begin{tabular}{|l|}
98 \\
$(21.77)$
\end{tabular} & $\begin{array}{l}121 \\
(26.88)\end{array}$ & $\begin{array}{l}320 \\
(71.11)\end{array}$ \\
\hline Female & $\begin{array}{l}49 \\
(10.88)\end{array}$ & $\begin{array}{l}52 \\
(11.55)\end{array}$ & $\begin{array}{l}29 \\
(6.44)\end{array}$ & $\begin{array}{l}130 \\
(28.88)\end{array}$ \\
\hline \multicolumn{5}{|l|}{ Education } \\
\hline Illiterate & $\begin{array}{l}121 \\
(26.88)\end{array}$ & $\begin{array}{l}129 \\
(28.66)\end{array}$ & $\begin{array}{l}127 \\
(28.22)\end{array}$ & $\begin{array}{l}337 \\
(83.88)\end{array}$ \\
\hline SSC & $\begin{array}{l}22 \\
(4.88) \\
\end{array}$ & $\begin{array}{l}14 \\
(3.11)\end{array}$ & $\begin{array}{l}16 \\
(3.55) \\
\end{array}$ & $\begin{array}{l}52 \\
(11.55)\end{array}$ \\
\hline Intermediate & $\begin{array}{l}5 \\
(1.11) \\
\end{array}$ & $\begin{array}{l}4 \\
(0.88)\end{array}$ & $\begin{array}{l}5 \\
(1.11) \\
\end{array}$ & $\begin{array}{l}14 \\
(3.11)\end{array}$ \\
\hline
\end{tabular}


International Journal of Trend in Scientific Research and Development (IJTSRD) ISSN: 2456-6470

\begin{tabular}{|c|c|c|c|c|}
\hline Graduation -tech & $\begin{array}{l}1 \\
(0.22)\end{array}$ & $\begin{array}{l}3 \\
(0.66)\end{array}$ & $\begin{array}{l}2 \\
(0.44)\end{array}$ & $\begin{array}{l}6 \\
(1.33)\end{array}$ \\
\hline Diploma & $\begin{array}{l}1 \\
(0.22)\end{array}$ & $\begin{array}{l}0 \\
(0.00)\end{array}$ & $\begin{array}{l}0 \\
(0.00)\end{array}$ & $\begin{array}{l}1 \\
(0.22)\end{array}$ \\
\hline \multicolumn{5}{|l|}{ Place of residence } \\
\hline Rural & $\begin{array}{l}120 \\
(26.66) \\
\end{array}$ & $\begin{array}{l}100 \\
(22.22) \\
\end{array}$ & $\begin{array}{l}120 \\
(26.66) \\
\end{array}$ & $\begin{array}{l}340 \\
(75.55) \\
\end{array}$ \\
\hline Urban & $\begin{array}{l}30 \\
(6.66) \\
\end{array}$ & $\begin{array}{l}50 \\
(11.11)\end{array}$ & $\begin{array}{l}30 \\
(6.66) \\
\end{array}$ & $\begin{array}{l}110 \\
(24.44)\end{array}$ \\
\hline \multicolumn{5}{|l|}{ Monthly income } \\
\hline Rs. 5000 and below & $\begin{array}{l}25 \\
(5.55) \\
\end{array}$ & $\begin{array}{l}15 \\
(3.33) \\
\end{array}$ & $\begin{array}{l}48 \\
(10.66)\end{array}$ & $\begin{array}{l}88 \\
(19.55)\end{array}$ \\
\hline Rs 5000 - 10000 & $\begin{array}{l}117 \\
(26.00)\end{array}$ & $\begin{array}{l}84 \\
(18.66)\end{array}$ & $\begin{array}{l}56 \\
(12.44) \\
\end{array}$ & $\begin{array}{l}257 \\
(57.11)\end{array}$ \\
\hline Rs $10001-15000$ & $\begin{array}{l}14 \\
(3.11) \\
\end{array}$ & $\begin{array}{l}16 \\
(3.55) \\
\end{array}$ & $\begin{array}{l}18 \\
(4.00) \\
\end{array}$ & $\begin{array}{l}48 \\
(10.66)\end{array}$ \\
\hline Above Rs. 20000 & $\begin{array}{l}4 \\
(0.88) \\
\end{array}$ & $\begin{array}{l}8 \\
(1.77) \\
\end{array}$ & $\begin{array}{l}45 \\
(10.00)\end{array}$ & $\begin{array}{l}57 \\
(12.66) \\
\end{array}$ \\
\hline
\end{tabular}

Source: Primary Data

The table 1 reveals the demographic profile of the respondents. The age of the respondents varied between below 30 years and above 50 years. The data reveals that the largest groups of the respondents are in the age group of above 50 years (39.33 percent). Out of the total, 28.44 per cent of the respondents are in 41-50 years age group and 26 per cent of the respondents belong to 31-40 years age group. The respondents who are in the age group of 30 years and below are very less in number representing 6.22 per cent. It can be inferred from the data that the handloom sector is unable to attract youngsters in to this profession. The gender wise distribution of respondents reveals that out of the total, 71.11 per cent of the respondents are males and/about 29 percent are females. The female respondents are relatively more in East Godavari and Ananthapur districts. The female respondents are less in number in Srikakulam district. The district wise educational background of the respondents shows that about 84 per cent of the respondents are illiterate persons. There are 11.55 per cent of the respondents who studied SSC. The respondents who completed intermediate education were 3.11 per cent. Graduates are 6 in number representing 1.33 per cent of the total, while 1 respondent completed diploma course.
The analysis regarding the place of residence shows that 76 per cent of the respondents belong to rural areas and while 24.44 per cent of the respondents carry out the profession in urban areas. The monthly family income of the respondents varied between Rs. 5,000 \& below and above Rs.20, 000. The monthly family income of 10.66 per cent of the respondents is in range of Rs. 10,000 to Rs. 15,000 and 57.11 per cent of the respondents varied between Rs.5,000 and Rs 10000 . There are 12.66 per cent of the respondents whose monthly income is more than Rs.20,000 while the monthly family income of 19.55 of the respondents was Rs.5,000 and below.

\section{Data Analysis}

The study attempts to know the opinion of the implementation of Integrated Handloom Cluster Development Scheme on weavers using mean and percentage score values. As per the findings of the study the null hypothesis on the member weavers have highly positive opinion on implementation of IHCDS rejected. The opinion of the respondents on handloom clusters has been calculated the data are presented in Table 2 As shown in the table the opinion of the respondents on the following statements have been ascertained on the mean scores. 
Table 2: Opinion on Clusters of Handloom Weavers

\begin{tabular}{|l|l|l|}
\hline Opinion on Cluster & Mean & $\begin{array}{l}\text { Percentage } \\
\text { Score }\end{array}$ \\
\hline IHDCS is highly beneficiary to handloom industry & 3.47 & 61.89 \\
\hline Weavers community will be benefited significantly & 3.52 & 63.17 \\
\hline The funds allocated for the schemes are sufficient to achieve the objectives & 1.48 & 12.17 \\
\hline The management system designed and implemented effectively & 1.62 & 15.61 \\
\hline The funds are utilized properly by the cluster & 1.62 & 15.50 \\
\hline The weavers' interests are taking care of & 2.63 & 40.78 \\
\hline The clusters gave new hope of revival of the industry & 2.45 & 36.44 \\
\hline New generation will be attracted to the industry & 2.55 & 38.83 \\
\hline $\begin{array}{l}\text { The clusters are capable of providing adequate marketing support for the } \\
\text { handloom products }\end{array}$ & 1.81 & 20.44 \\
\hline Clusters are providing required infrastructure for producing quality fabrics & 1.53 & 13.39 \\
\hline $\begin{array}{l}\text { Training programmes organized by the clusters really contributed for skill } \\
\text { development }\end{array}$ & 1.65 & 16.39 \\
\hline Average & 2.21 & 30.41 \\
\hline
\end{tabular}

\section{Source: Primary Data}

The statement weaving community benefited significantly got the highest mean value of (3.52) all the other statements got the mean value of less than three. The statement the funds allocated for the schemes are sufficient to achieve the objectives got the lowest rating (mean score 1.48) followed by statement 'Clusters are providing required infrastructure for producing quality fabrics (mean score 1.53)'. It indicates from the data that the respondents are not satisfied with the implementation of the scheme and at the same time they are hopeful of better result of the schemes in future.

Table 3: Respondents having Health Insurance Policy

\begin{tabular}{|c|c|c|c|c|}
\hline \multirow{2}{*}{ Opinion } & \multicolumn{3}{|c|}{ District } & \multirow{2}{*}{ Total } \\
\cline { 2 - 5 } & Ananthapur & East Godavari & Srikakulam & 107 \\
\multirow{2}{*}{ Yes } & 61 & 39 & 7 & $(23.77)$ \\
\hline \multirow{2}{*}{ No } & $(13.55)$ & $(8.66)$ & $1.55)$ & 343 \\
& $(19.77)$ & 111 & $(31.77)$ & $(76.22)$ \\
\hline \multirow{2}{*}{ Total } & 150 & $(24.66)$ & 150 & 450 \\
& $(33.33)$ & $(33.33)$ & $(33.33)$ & $(100.00)$ \\
\hline
\end{tabular}

Chi-square: 54.244, P-Value: 0.00, Significant

Source: Primary data.

The study reveals that 23.77 per cent of the respondents are having health insurance (Table 3 ). The Chi-square: 54.244, P-Value: 0.00 establishes the fact that there is a significant variation among the districts as far as status of health insurance policy is concerned. Relatively more number of respondents from Ananthapur district has taken health insurance policy followed by East Godavari. Very few respondents from Srikakulam district have taken health insurance policy. 


\section{Results and Discussions}

MLR (Multiple Linear Regressions) analysis was carried out to study and establish the relationship between the demographic factors (District Gender,
Age, Education and Monthly Income) of respondents and Impact of social conditions on handloom cluster weavers as shown in table 4.

\section{Table 4: Regression Analysis:}

\section{Opinion on handloom clusters versus District, Gender, Age, Education and Income}

\begin{tabular}{|l|l|l|l|l|l|}
\hline Source & DF & Adj. SS & Adj. MS & F-Value & P-Value \\
\hline Regression & 13 & 1.3487 & 0.10375 & 3.53 & 0 \\
\hline District & 2 & 1.013 & 0.50648 & 17.22 & 0 \\
\hline Gender & 1 & 0.0169 & 0.01689 & 0.57 & 0.449 \\
\hline Age & 3 & 0.1981 & 0.06603 & 2.25 & 0.082 \\
\hline Education & 4 & 0.1099 & 0.02747 & 0.93 & 0.444 \\
\hline Income & 3 & 0.1677 & 0.0559 & 1.9 & 0.129 \\
\hline Error & 436 & 12.8207 & 0.02941 & & \\
\hline Lack-of-Fit & 96 & 2.3409 & 0.02438 & 0.79 & 0.915 \\
\hline Pure Error & 340 & 10.4797 & 0.03082 & & \\
\hline Total & 449 & 14.1693 & & & \\
\hline R-sq 9.52\% & & & & & \\
\hline
\end{tabular}

\section{Source: Primary Data}

The R-Square value shows that regression model explains 9.52 per cent of the variance in strength, indicating that the model does not fits the data fairly well. The R-square value considers the regression equation in the model and examines the strength of the independent variables in predicting the dependent variable. It exemplifies that there is no significant linear relationship between the demographic factors extracted above and their probability of association with various statements related to implementation of IHCDS of handloom cluster weavers. Only one variable (District) out of five contributed significantly to the equation at 5 per cent level i.e., the analysis of variance table indicates that the relationship between district and economic conditions is significant $(\mathrm{P}=$ 0.000 ) shown in table 5.

Table 5: ANOVA's Test Results towards Statements on Impact of Handloom Clusters of Respondents

\begin{tabular}{|l|l|l|l|l|l|}
\hline District & N & Mean & SD & $\begin{array}{l}\text { F- } \\
\text { Value }\end{array}$ & $\begin{array}{l}\text { P- } \\
\text { Value }\end{array}$ \\
\cline { 1 - 4 } Ananthapur & 150 & 2.1624 & 0.145 & 15.59 & 0.000 \\
\cline { 1 - 3 } $\begin{array}{l}\text { East } \\
\text { Godavari }\end{array}$ & 150 & 2.2733 & 0.1941 & & \\
\cline { 1 - 4 } Srikakulam & 150 & 2.2145 & 0.1738 & & \\
\hline
\end{tabular}

Thus, the finding of the study rejects the null hypothesis. So 'the member weavers have no positive opinion on implementation of IHCDS'.

\section{Conclusion}

The opinion of the respondents on handloom clusters has been calculated on the eleven statements. The statement weaving community benefited significantly got the highest mean value of (3.52) all the other statements got the mean value of less than three. The statement 'the funds allocated for the schemes are sufficient to achieve the objectives' got the lowest rating (mean score 1.48) followed by statement 'Clusters are providing required infrastructure for producing quality fabrics (mean score 1.53)'. It indicates from the data that the respondents are not satisfied with the implementation of the scheme and at the same time they are hopeful of better result of the schemes in future.

Handloom sector is highly labor intensive industry with low capital investment. It is also a low energy sector with no adverse impact on the environment as weaving is a totally pollution free activity. The strength of handloom lies in the introducing innovative designs, which cannot be replicated by the 
power loom sector. The impact of social conditions is assessed based on the opinion of the respondents on the following six statements expressed on five point scale ranking between sternly agree to strongly disagree. Membership in cluster enhanced social status of the weavers, all the family members find full time work under the scheme, taken care of children education, the quality of family life enhanced, future is secured under the scheme, and increased harmony in social relations.

\section{REFERENCES}

1. Annapurana M, Transitioning, (2006), "Markets Transcending Consumption", Economic and Political Weekly, Vol. 41, No.31, August, pp3388-3393.

2. Asha Krishnakumar, (2003), "A Great Tradition in Decline", Frontline, the Indian's national magazine from publish of the Hindu, Vol.2, Issue.18, August 30 -September 12.

3. Ashis Mitra, Prabir kumar choudhuri, and Arup mukherjee, (2009), "A Diagnostic Report on Cluster Development Programme of Shantipur Handloom Cluster, Nadia, West Bengal", Part 1 Evolution of the Cluster and Cluster Analysis, Indian Journal of Traditional Knowledge, Vol. 8, No.4, October, pp. 502-509.

4. Bharathan, K., (1988), "The Handloom Industry in Tamil Nadu: A Study of Organizational Structure", University of Madras.

5. Enright, M., (1998), "Regional clusters and firm strategy, the dynamic firm, the role of technology, strategy, organization and regions", Oxford University Press, Oxford.

6. Fayaz, Ahmad., Nengroo A. Hussain, (2013), “An analysis of Handloom Sector of Jammu and Kashmir; A Case Study of District Budgam", International Journal of Management and Business Studies, Vol. 3(1), pp. 106.

7. Jayavel R., (2013), "Blow of Textile Industry on Member Weavers's of Silk Handloom Cooperative Societies in Kanchipuram District", Asia Pacific Journal of Marketing and Management Review, Vol. (2) 4, pp.22-29.

8. Joglekar and Prabhakara Sharma (2003), Up gradation of Handloom Co-operative, Indian Cooperative Review, Vol.39, No. 3, January, p-235.
9. Krishna Reddy. Ch. V and Noorbasha abdul (2013), "Economic Reforms - Declining Handloom Industry, Role of Microfinance", American International Journal of Research in Humanities, Arts and Social Sciences, Vol.4, No.1, September- November, pp-66-72.

10. Kuldeep Singh and Monica Bansal, (2012), "A Review of Handloom Export Units in India", Abhinav National Monthly Refereed Journal of Research In Commerce \& Management, Vol.1, Issue .11, 2012, pp-185-191.

11. Laxmi Narasaiah M, (2004), "Economics of Handloom Industry", Sonali Publications, New Delhi.

12. Margaret C. Perivoliotis, (2009), "Weaving Techniques Inspire Modern Jewels", fibre2fashion.com, published on Tuesday, September 08 .

13. Merima ali, (2010), "Clustering as an Organizational Response to Capital Market inefficiency", International Food Policy Research institute, December, pp.1-26.

14. Mukund, K and B. Syamasundari, (2001), "Traditional Industry in the New Market Economy-The Cotton Handlooms of Andhra Pradesh", New Delhi: Sage Publications.

15. Pani.B.S, (1990), "Handloom Development Policy - A Critical Appraisal", Journal of Rural Development, Vol. 9, No.2, pp.406-416.

16. Porter, M. E., (1998), "Clusters and New Economics of Competition", in Harvard Business Review, Nov - Dec., pp.77-90.

17. Rachana Goswami and Ruby Jain, (2014), "Strategy for sustainable Development of Handloom Industry", Global Journal of Finance and Management, Vol.6, November-2, pp. 93-98.

18. Rama Mohan Rao. K. (1990), "Development of Handloom Industry”, Discovery Publishing House, New Delhi.

19. Rayapati Raveendra Nadh (2013), "Handloom market, Need for Market Assessment, problems and Marketing Strategy", International Journal of Emerging Research in Management and Technology, Vol.2, Issue.5, May, pp.6-11.

20. Reguladevi A.K. (1983), "Plight of Handloom Weavers-A Study”, Kurukshethra, 1st January. 
21. Schmitz, H., (1999), "Responding to Global Competitive Pressure: Local Co-operation and Upgrading in the Sinos Valley, Brazil”, IDS Working Paper 82, Brighton: IDS.

22. Sinha. R, (2005), "Status of Women and Economic Development", Some Econometric Evidence, RBSA Publishers, pp.25-49.

23. Srinivasa Rao and Kasisomayajula, (2012), "Socio-Economic Analysis of Handloom Industry in Andhra Pradesh" Study on Selected Districts, Journal of Exclusive Management Science, September, Vol.1, Issue.8, pp.1-15.

24. Tasneem Shazli and Abdul Munir, (2014), "Female Work Participation in Handloom Industry-A Case Study of Mubarakpur Town, Azamgarh District, U.P.”, Journal of Education and Social Policy Vol. 1, No. 1, June, pp. 76-83.

25. Van Dijk, T. A., (2000), Parliamentary Debates, Dins Wodak, R.; van Dijk, T. A. (eds.) (2000), Racism at the Top. Parliamentary Discourses on Ethnic Issues in Six European States. Klagenfurt, Austria: Drava Verlag, 45-78.

26. Vijayabhaskar.R, (2014), "Increased Import Duty on China Silk- Shutdown The Handloom Industry", Online International Interdisciplinary Research Journal, Vol. 4, Special Issue, Jan, pp.365-369 